\title{
Responsanalyse schoolverlatersonderzoeken. ROA meting 2013
}

Citation for published version (APA):

Belfi, B. E., \& Huijgen, T. G. (2015). Responsanalyse schoolverlatersonderzoeken. ROA meting 2013. ROA. ROA Technical Reports No. 003 https://doi.org/10.26481/umarot.2015003

Document status and date:

Published: 01/01/2015

DOI:

10.26481/umarot.2015003

Document Version:

Publisher's PDF, also known as Version of record

\section{Please check the document version of this publication:}

- A submitted manuscript is the version of the article upon submission and before peer-review. There can be important differences between the submitted version and the official published version of record.

People interested in the research are advised to contact the author for the final version of the publication, or visit the DOI to the publisher's website.

- The final author version and the galley proof are versions of the publication after peer review.

- The final published version features the final layout of the paper including the volume, issue and page numbers.

Link to publication

\footnotetext{
General rights rights.

- You may freely distribute the URL identifying the publication in the public portal. please follow below link for the End User Agreement:

www.umlib.nl/taverne-license

Take down policy

If you believe that this document breaches copyright please contact us at:

repository@maastrichtuniversity.nl

providing details and we will investigate your claim.
}

Copyright and moral rights for the publications made accessible in the public portal are retained by the authors and/or other copyright owners and it is a condition of accessing publications that users recognise and abide by the legal requirements associated with these

- Users may download and print one copy of any publication from the public portal for the purpose of private study or research.

- You may not further distribute the material or use it for any profit-making activity or commercial gain

If the publication is distributed under the terms of Article $25 \mathrm{fa}$ of the Dutch Copyright Act, indicated by the "Taverne" license above, 


\section{Responsanalyse schoolverlatersonderzoeken}

ROA meting 2013

Barbara Belfi

Timo Huijgen

\section{ROA Technical Report}

ROA-TR-2015/3

Researchcentrum voor Onderwijs en Arbeidsmarkt | ROA

Research Centre for Education and the Labour Market | ROA 


\title{
Responsanalyse schoolverlatersonderzoeken
}

\author{
ROA meting 2013
}

\author{
Barbara Belfi \\ Timo Huijgen
}

ROA-TR-2015/3

May 2015

Research Centre for Education and the Labour Market Maastricht University

P.O. Box 616, 6200 MD Maastricht, The Netherlands

$\mathrm{T}+31433883647 \mathrm{~F}+31433884914$

secretary-roa-sbe@maastrichtuniversity.nl www.roa.nl 


\section{Inhoud}

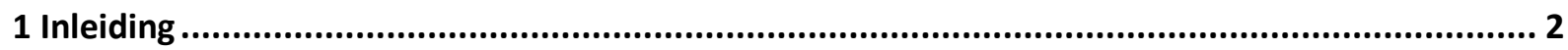

1.1 Algemeen: non-respons in surveyonderzoek ................................................................. 2

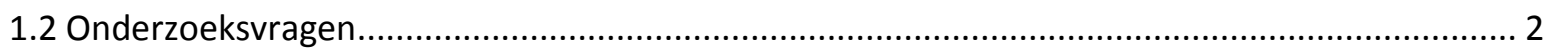

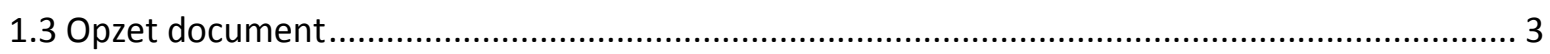

2 Data

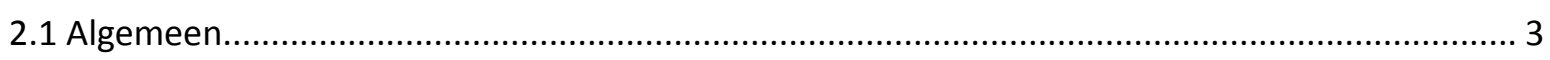

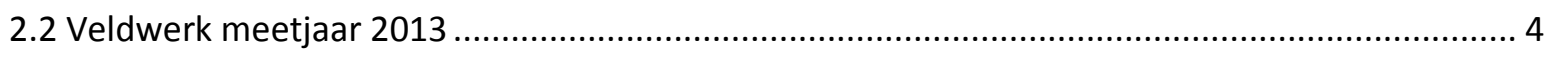

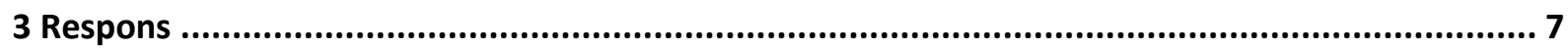

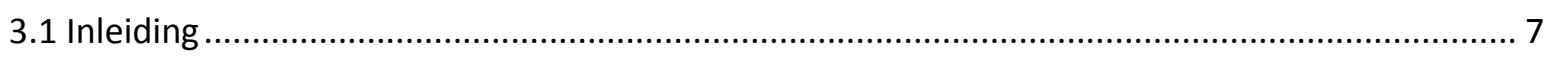

3.1.1 De invloed van enquête- en persoonsgebonden kenmerken op de respons ........................ 8

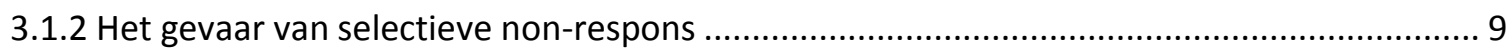

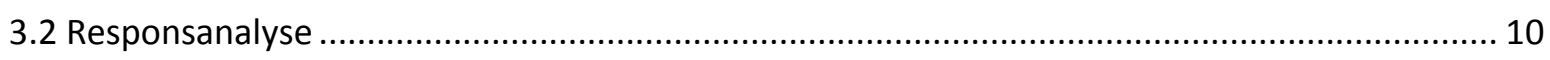

4 Het effect van het toevoegen van een schriftelijke vragenlijst............................................. 12

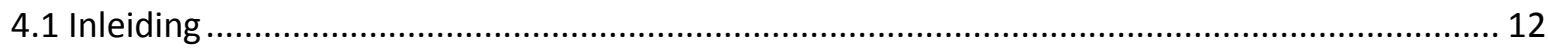

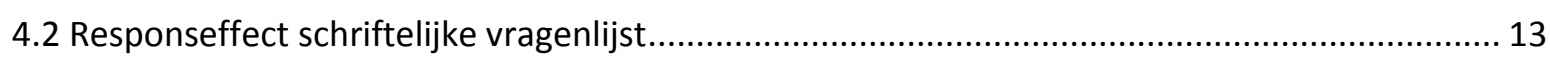

4.3 Verschillen in samenstelling respondentgroepen internet versus schriftelijk ........................... 14

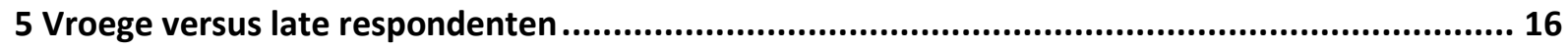

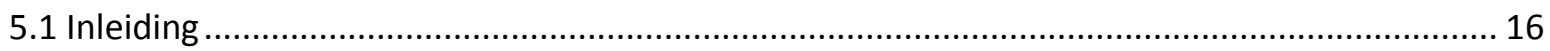

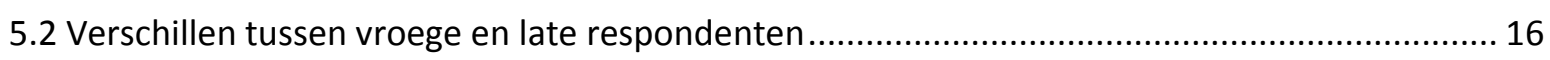

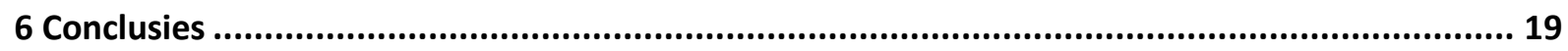

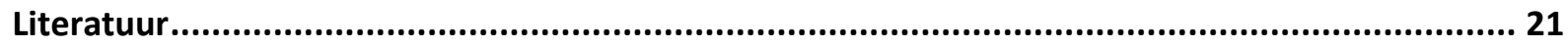

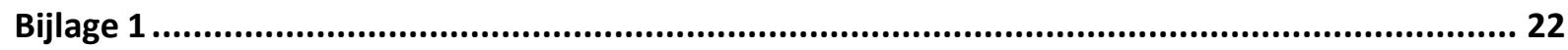

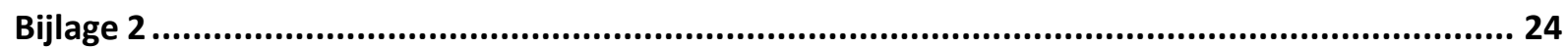




\section{Inleiding}

\subsection{Algemeen: non-respons in surveyonderzoek}

Bij survey onderzoek wordt er naar gestreefd een zo hoog mogelijk responscijfer te behalen. Omdat er echter zowel logistieke als financiële beperkingen zijn zal er altijd een groep van de benaderde personen blijven bestaan die niet reageert en dus niet deelneemt aan het onderzoek. Deze nonrespons zal leiden tot een lager aantal waarnemingen in het uiteindelijke databestand. Dit hoeft echter niet noodzakelijkerwijs te leiden tot onjuiste uitkomsten of statistieken ${ }^{1}$.

Het kan echter een probleem worden wanneer de non-respons selectief is waardoor bepaalde groepen onder- of oververtegenwoordigd raken in het onderzoek. Indien in dit geval deze groepen zich anders gedragen als het om de te onderzoeken indicatoren gaat kan dit leiden tot vertekeningen in de uitkomsten. Schattingen vallen dan systematisch te hoog of te laag uit. Indien bijvoorbeeld de respons afneemt naarmate men ouder is en het vinden van een baan als schoolverlater ook moeilijker wordt naarmate men ouder is zal dit niet alleen leiden tot relatief te weinig oudere schoolverlaters in het onderzoeksbestand maar ook tot een onderschatting van de werkloosheid. Uit onderzoek en de bijbehorende literatuur is al vaak gebleken dat er sprake is van selectieve respons. Zo is non-respons al vaker in verband gebracht met leeftijd, etniciteit en sociaal economische status (SES, welke vaak afgeleid wordt aan de hand van opleidingsniveau, inkomen e.d.). Maar ook het onderwerp van de survey en de mate van verstedelijking van de woonplaats van de beoogde respondent spelen een rol. $^{2}$

Behalve deze zogenaamde unit non-respons, kan er daarnaast sprake zijn van item non-respons. Item non-respons is non-respons op het niveau van individuele vragen in de vragenlijst. Wanneer iemand wel deelneemt aan het onderzoek maar geen antwoord geeft op een bepaalde vraag is er sprake van item non-respons. Zo kennen bijvoorbeeld vragen over inkomen en seksuele geaardheid een hogere item non-respons dan minder persoonlijke vragen. Ook hier is het gevaar van selectieve item nonrespons belangrijk. Los van het feit dat een hoge item non-respons zijn oorzaak kan hebben in een slechte, onduidelijke vraagstelling kan selectiviteit leiden tot een vertekening van de schattingen op basis van deze vraag. Deze item non-respons wordt in dit document echter niet verder behandeld.

\subsection{Onderzoeksvragen}

Sinds 1991 voert het Researchcentrum voor Onderwijs en Arbeidsmarkt (ROA) van de Maastricht University grootschalige onderzoeken uit onder recent gediplomeerde schoolverlaters en afgestudeerden van het bekostigd onderwijs in Nederland. Hierbij worden de te benaderen personen $z o ' n$ anderhalf jaar na het behalen van het diploma verzocht een vragenlijst in te vullen ${ }^{3}$. Ter evaluatie van de kwaliteit van de databestanden, en de met deze databestanden gegenereerde statistieken en rapporten, wordt in dit document gekeken in welke mate selectiviteit van respons een rol speelt bij de jaarlijkse schoolverlatersonderzoeken. Centrale onderzoeksvragen hierbij zijn:

1. Wat is de invloed van bepaalde achtergrondkenmerken op de respons?

2. Wat is de invloed van het meesturen van een papieren vragenlijst op de respons?

\footnotetext{
${ }^{1}$ Zie Bethlehem (2008).

${ }^{2}$ Zie onder andere Stoop (2005) en Feskens en Hox (2007).

${ }^{3}$ Het onderzoek wordt in samenwerking met DESAN Research Solutions uitgevoerd dat het veldwerk van de enquêtes verzorgt.
} 
3. Zijn er verschillen tussen de respons van respondenten die direct bereid zijn om aan het onderzoek mee te doen (i.e., 'vroege respondenten') en de respons van respondenten die pas in een laat stadium, dat wil zeggen na meerdere benaderingen, bereid zijn om mee te doen (i.e., 'late respondenten')?

4. Moet er naar aanleiding van de antwoorden op bovengenoemde vragen iets aan de onderzoeksopzet van de ROA schoolverlatersonderzoeken veranderd worden?

\subsection{Opzet document}

In dit document wordt onderzocht in hoeverre op deze centrale onderzoeksvragen een antwoord gegeven kan worden. De analyses en de gevonden resultaten hebben alleen betrekking op de schoolverlatersonderzoeken van het ROA en moeten ook als zodanig geïnterpreteerd worden.

In hoofdstuk 2 geven we allereerst een korte uitleg over de ROA schoolverlatersonderzoeken en de voor de analyses gebruikte data. Hoofdstuk 3 gaat vervolgens nader in op de invloed van persoonlijke achtergrondkenmerken op de respons. Responderen mannen bijvoorbeeld slechter dan vrouwen en wat is de invloed van het behaalde opleidingsniveau op de bereidheid om deel te nemen aan de enquête? Wat de invloed is van zogenaamde mixed-mode enquêtes op de respons en of het achterwege laten van schriftelijke vragenlijsten tot een daling in de responscijfers leidt komt in hoofdstuk 4 aan orde. In hoofdstuk 5 wordt voorts getracht een vergelijking te maken tussen zogenaamde 'late' respondenten en 'vroege' respondenten. Een afwijking tussen deze twee groepen op belangrijke indicatoren kan betekenen dat het niet noodzakelijkerwijs een goede strategie is om het over de streep halen van respondenten tot in den treuren door te voeren. In het laatste hoofdstuk wordt tenslotte een en ander samengevat en gekeken wat mogelijke verbeterpunten zijn voor de ROA schoolverlatersonderzoeken naar aanleiding van de analyses.

\section{Data}

\subsection{Algemeen}

Het ROA voert sinds 1991 op structurele basis schoolverlatersonderzoeken uit. Deze onderzoeken zijn gericht op het in kaart brengen van de transitie van gediplomeerde schoolverlaters van het onderwijs naar de arbeidsmarkt en het in kaart brengen van de positie van gediplomeerden in het vervolgonderwijs. Daarbij gaat het niet alleen om kwantitatieve indicatoren zoals stroompercentages en werkloosheidscijfers maar ook om de kwaliteit van de aansluiting op zowel het vervolgonderwijs als de arbeidsmarkt alsook de oordelen van de afgestudeerden over hun gevolgde opleiding. Bij de onderzoeken worden afgestudeerden van het Algemeen Vormend Onderwijs (avo) en het Voorbereidend Middelbaar Beroeps Onderwijs (vmbo) (VO-monitor), het Middelbaar Beroeps Onderwijs (BVE-monitor) en het Hoger Beroeps Onderwijs (HBO-monitor) ongeveer anderhalf jaar na het behalen van het diploma benaderd.

Het ROA voert daarnaast ook op structurele basis onderzoek uit onder ongediplomeerde schoolverlaters, door middel van de VSV-monitor. Hierbij worden voortijdig schoolverlaters van het vo en het mbo bevraagd over onder andere hun redenen voor het voortijdig verlaten van hun studie en hun bezigheden na het verlaten hun studie. 


\subsection{Veldwerk meetjaar 2013}

De data die gebruikt zijn voor de analyses in het huidige document zijn afkomstig van de monitoren van meting 2013. Hierbij zijn in het najaar (september/oktober) van 2013 de afgestudeerden voor de eerste keer benaderd met het verzoek aan het onderzoek deel te nemen door middel van het invullen van een vragenlijst. Het gaat hierbij om jongeren die in het studiejaar 2011/2012 een diploma behaald hebben dan wel in dat schooljaar de opleiding ongediplomeerd verlaten hebben.

Voor de meeste onderzoeken kunnen scholen zich integraal opgeven om deel te nemen. De bronbestanden op basis waarvan de adressen worden geselecteerd, en eventuele steekproeven worden getrokken kunnen per monitor verschillen. Hieronder volgt per monitor een korte beschrijving.

VO-monitor: voor de VO-monitor wordt een steekproef getrokken op basis van de onderwijsbestanden van DUO. ${ }^{4}$ De populatie bestaat uit havo, vwo en vmbo scholieren die in het schooljaar 2011/2012 het diploma hebben behaald. Scholen hebben de mogelijkheid om integraal deel te nemen aan de monitor en kunnen er zelfs voor kiezen de adressen zelf aan te leveren en/of zelf de enquête te versturen. Indien verzending op basis van de naam, adres en woonplaats (NAW)gegevens afkomstig van de DUO bestanden plaatsvindt, wordt de verzending van de mailingen door het verzendhuis van DUO uitgevoerd en niet door DESAN ${ }^{5}$. Dit omdat DUO vanwege de privacywetgeving geen adressen aan derden verstrekt.

BVE-monitor: voor de BVE-monitor wordt eveneens een steekproef getrokken op basis van de onderwijsbestanden van DUO. De populatie bestaat zowel uit gediplomeerden van de beroepsopleidende leerweg (bol) als uit gediplomeerden van de beroepsbegeleidende leerweg (bbl) die in het schooljaar 2011/2012 het diploma hebben behaald. Ook hier hebben scholen de mogelijkheid om integraal deel te nemen aan de monitor en kan de verzending door de scholen zelf op basis van eigen adressen in plaats van de registerbestanden van DUO gebeuren. In verband met de uitvoering van een ander project van het $\mathrm{ROA}^{6}$, dat in aanvulling op de reguliere schoolverlatersonderzoeken wordt uitgevoerd, is in meting 2013 na deze eerste steekproeftrekking, de steekproef uitgebreid naar de totale populatie. Omdat bij deze tweede groep (i.e., 'de mbo II uitbreiding') enkel gebruik is gemaakt van een digitale vragenlijst en geen gebruik is gemaakt van een schriftelijke vragenlijst kan deze sub steekproef gebruikt worden om het effect van het bijvoegen van schriftelijke vragenlijsten (in aanvulling op digitale vragenlijsten) op de respons na te gaan (zie hoofdstuk 4).

HBO-monitor: de steekproef van de HBO-monitor is volledig gebaseerd op de deelname van individuele hogescholen. Verzending gebeurt op basis van de adressen uit administratiebestanden van hogescholen. Een hogeschool kan er voor kiezen om de verzending zelf te doen (decentraal) of centraal door DESAN te laten verzorgen. Meer dan $80 \%$ van de hogescholen neemt deel aan de HBOmonitor. Voor meetjaar 2013 gaat het om hbo afgestudeerden die tussen 1 september 2011 en 31 augustus 2012 het diploma behaald hebben. Bachelor afgestudeerden behoren standaard tot de

\footnotetext{
${ }^{4}$ Dienst Uitvoering Onderwijs van het Ministerie van OCW

${ }^{5}$ DESAN Research Solutions is het bureau dat het veldwerk verzorgt van de schoolverlatersonderzoeken van het ROA.

${ }^{6}$ Evaluatie School-ex programma 2.0
} 
populatie. Hogescholen hebben daarnaast de optie om hun master en/of associate degree (ad) afgestudeerden eveneens te laten benaderen.

VSV-monitor: voor de VSV-monitor wordt een steekproef getrokken op basis van de onderwijsbestanden van DUO. De populatie bestaat uit personen die in het schooljaar 2011/2012 een opleiding in het avo, vmbo of het mbo gevolgd hebben en hier geen diploma van behaald hebben. Daarnaast waren zij in oktober van 2012 niet meer in het onderwijs ingeschreven ${ }^{7}$, jonger dan 23 jaar en niet in het bezit van een startkwalificatie (i.e., een diploma op minimaal mbo niveau 2 of avo-diploma).

In Tabel 2.1 staan enkele inhoudelijke cijfers over de uitvoering van het veldwerk van meting 2013. Over het algemeen vinden er drie mailingen plaats ${ }^{8}$. Met uitzondering van de 'mbo II uitbreiding' steekproef hebben alle benaderden op enig moment een schriftelijke vragenlijst toegezonden gekregen. Vanwege de hoge internetrespons en vanwege de hoge kosten waarmee het verzenden en verwerken van schriftelijke vragenlijsten gepaard gaat, wordt bij de HBO-monitor pas bij de tweede mailing een schriftelijke vragenlijst bijgevoegd. Bij de centrale verzending die via DESAN gebeurd, is het voor onderwijsinstellingen (in de praktijk dus met name hogescholen) mogelijk om eigen logo's en eigen briefpapier te laten gebruiken. Doordat bij de andere monitoren vrijwel alles via DUO verloopt is dat bij deze monitoren helaas niet mogelijk. Uit de tabel blijkt dat er nog steeds aanzienlijke groepen respondenten zijn die, indien de mogelijkheid geboden wordt, de schriftelijke vragenlijst gebruiken.

Tabel 2.1 Veldwerk meting 2013

\begin{tabular}{|c|c|c|c|c|c|c|c|}
\hline & & vmbo & avo & $\begin{array}{l}\text { mbo I } \\
\text { regulier }\end{array}$ & $\begin{array}{l}\text { mbo II } \\
\text { uitbreiding }\end{array}$ & hbo & ongedipl. \\
\hline \multirow[t]{2}{*}{ Eerste mailing: } & Wijze benaderen & post & post & post & post & $\begin{array}{l}\text { e-mail en } \\
\text { post }\end{array}$ & post \\
\hline & $\begin{array}{l}\text { Vragenlijst } \\
\text { bijgevoegd }\end{array}$ & $\mathrm{Ja}$ & ja & ja & nee & nee & ja \\
\hline \multirow{2}{*}{$\begin{array}{l}\text { Tweede } \\
\text { mailing: }\end{array}$} & Wijze benaderen & post & post & post & post & post & post \\
\hline & $\begin{array}{l}\text { Vragenlijst } \\
\text { bijgevoegd }\end{array}$ & nee & nee & nee & nee & ja & nee \\
\hline \multirow[t]{3}{*}{ Derde mailing: } & Wijze benaderen & post & post & post & post & post & post \\
\hline & $\begin{array}{l}\text { Vragenlijst } \\
\text { bijgevoegd }\end{array}$ & nee & nee & nee & nee & ja & nee \\
\hline & $\begin{array}{l}\text { Telefonische } \\
\text { herinnering }\end{array}$ & nee & nee & nee & nee & ja & nee \\
\hline \multirow[t]{3}{*}{ Verzending: } & Centraal DUO & $100 \%$ & $100 \%$ & $93,9 \%$ & $100 \%$ & & $100 \%$ \\
\hline & Centraal DESAN & & & $2,3 \%$ & & $99,6 \%$ & \\
\hline & Decentraal & & & $3,7 \%$ & & $0,4 \%$ & \\
\hline
\end{tabular}

${ }^{7}$ Het gaat hier om ingeschreven staan in het door de overheid bekostigde onderwijs. DUO heeft geen informatie over inschrijvingen in het niet door de overheid bekostigde onderwijs.

${ }^{8} \mathrm{Bij}$ de HBO-monitor worden afgestudeerden in eerste instantie via e-mail benaderd. Afgestudeerden waarvan geen e-mail adres bekend is of niet hebben gereageerd op de eerste e-mail worden schriftelijk benaderd. Na de tweede en derde mailing wordt indien mogelijk telefonisch contact opgenomen en tenslotte nogmaals een email verstuurd. 


\begin{tabular}{|l|l|l|l|l|l|l|l|}
\hline & & vmbo & avo & $\begin{array}{l}\text { mbo I } \\
\text { regulier }\end{array}$ & $\begin{array}{l}\text { mbo II } \\
\text { uitbreiding }\end{array}$ & hbo & ongedipl. \\
\hline Adressen: & DUO & $100 \%$ & $100 \%$ & $93,9 \%$ & $100 \%$ & & $100 \%$ \\
\hline & Onderwijsinstelling & & & $6,1 \%$ & & $100 \%$ & \\
\hline & & & & & & & \\
\hline $\begin{array}{l}\text { Wijze van } \\
\text { responderen: }\end{array}$ & Internet & $47,7 \%$ & $67,9 \%$ & $57,5 \%$ & $100 \%$ & $87 \%$ & $54,7 \%$ \\
\hline & Schriftelijk & $52,3 \%$ & $32,1 \%$ & $42,5 \%$ & & $13 \%$ & $45,3 \%$ \\
\hline & & & & & & & \\
\hline
\end{tabular}

Tabel 2.2 toont de aantallen van afgestudeerden voor de gehele populatie, de steekproef, en het uiteindelijke bestand van respondenten. In de tabel staan eveneens enkele cijfers met betrekking tot het geslacht, de regio en het percentage niet-westerse allochtonen. Bijlage 1 bevat een meer uitgebreid overzicht van enkele basiskenmerken van de drie verschillende groepen. In het mbo is vrijwel de gehele populatie benaderd en ook in het hbo ligt, door de grote deelname van hogescholen aan de HBO-monitor, de totale steekproef dicht tegen de populatie aan. In het vo en bij de groep ongediplomeerde schoolverlaters wordt een aanzienlijk kleiner percentage van de populatie benaderd. In het mbo is er eigenlijk geen sprake van een steekproeftrekking, in ieder geval niet in 2013, en wordt vrijwel de gehele populatie benaderd. Door de opzet van de HBO-monitor is ook hier geen sprake van het trekken van een steekproef. In het vo worden eerst de deelnemende scholen geselecteerd en wordt op basis van het restant van de populatie een aselecte steekproef getrokken. Uit Tabel 2.2 blijkt allereerst dat voor de drie getoonde achtergrondkenmerken (i.e., geslacht, regio, en etnische achtergrond) de verschillen tussen de steekproef en de populatie gering zijn. Uit Bijlage 1 blijkt echter dat er wel een aanzienlijk verschil is in de verdeling over de onderwijssectoren in het vmbo. In het vmbo is bijvoorbeeld de sector landbouw in de steekproef procentueel aanzienlijk groter dan in de populatie. Doordat er voor de sector landbouw bij de steekproeftrekking zowel in het vmbo als het mbo gediplomeerden van Agrarische OpleidingsCentra (AOC) altijd voor een bepaald percentage benaderd moeten worden ${ }^{9}$, leidt dit in het vmbo tot een procentueel groter aandeel benaderden van de sector landbouw in de steekproef. Voor het mbo heeft dit geen effect omdat uiteindelijk in meting 2013 de gehele populatie benaderd is.

Het verschil tussen de aantallen van afgestudeerden in de steekproeven en het responsbestand wordt bepaald door de respons op de enquête. Uit Tabel 2.2. blijkt bijvoorbeeld dat vrouwen vaker responderen dan mannen. Niet-westerse allochtonen zijn daarentegen weer wat minder vertegenwoordigd in het responsbestand dan verwacht mag worden op basis van de steekproef. Uit de tabel uit Bijlage 1 blijkt eveneens dat ook de gediplomeerden van de lagere onderwijsniveaus minder geneigd zijn deel te nemen aan het onderzoek dan gediplomeerden van de hogere onderwijsniveaus. Zowel in het vmbo, het vo, als het mbo is er bij de procentuele verdeling binnen ieder onderwijstype een lichte verschuiving naar de hogere niveaus in de responsbestanden ten opzichte van de verdeling in de populatiebestanden. Wat precies de invloed van een oververtegenwoordiging van bepaalde achtergrondkenmerken op de respons is, komt in het volgende hoofdstuk aan de orde.

\footnotetext{
${ }^{9}$ Vanwege het belang van het onderzoek voor de agrarische sector wordt bij AOC's altijd minimaal $20 \%$ van de totale populatie op instellingsniveau benaderd.
} 
Tabel 2.2 Kenmerken populatie, steekproef en responsbestand

\begin{tabular}{|l|l|l|l|}
\hline & Populatie & Steekproef & Responsbestand \\
\hline Aantal & $n$ & $n$ & $n$ \\
\hline vo & 163.242 & 11.536 & 3.282 \\
\hline mbo & 157.279 & 151.208 & 31.324 \\
\hline hbo & 63.856 & 57.604 & 21.830 \\
\hline ongedipl. & 39.831 & 10.804 & 1.839 \\
\hline & & & \\
\hline$\%$ vrouw & $\%$ & $\%$ & $\%$ \\
\hline vo & 50 & 52,3 & 63,3 \\
\hline mbo & 48,7 & 48,8 & 57,4 \\
\hline hbo & 59,1 & 59,3 & 59,7 \\
\hline ongedipl. & 39,1 & 39,3 & 49,6 \\
\hline & & & \\
\hline$\%$ West-Nederland & $\%$ & $\%$ & $\%$ \\
\hline vo & $\%$ & 41,2 & 40,4 \\
\hline mbo & 44,7 & 42,7 & 40,5 \\
\hline hbo & 42,9 & 46 & 44,4 \\
\hline ongedipl. & 43,2 & 52,7 & 50,1 \\
\hline & 49,9 & & \\
\hline$\%$ niet-westerse allochtonen & & $\%$ & $\%$ \\
\hline vo & $\%$ & 11,9 & 8,3 \\
\hline mbo & 13,1 & 18,4 & 14 \\
\hline hbo & 18,4 & -- & 6,9 \\
\hline ongedipl. & 10 & 26,7 & 18,7 \\
\hline & 27,5 & & \\
\hline & & & \\
\hline & & & \\
\hline
\end{tabular}

\section{Respons}

\subsection{Inleiding}

In Nederland liggen de responscijfers in vergelijking met andere landen relatief laag. ${ }^{12}$ Daarnaast is er in de afgelopen twee decennia sprake van een dalende tendens in de responscijfers bij survey onderzoeken ${ }^{13}$. Alhoewel er de afgelopen jaren sprake is van een stabilisering laten ook de schoolverlatersonderzoeken van het ROA een dalende trend zien in de hoogte van de responscijfers (zie Figuur 3.1). Het lijkt er dus op dat men in Nederland steeds minder bereid is mee te werken aan enquêtes en er 'enquêtemoeheid' is ingetreden. Toch is deze enquêtemoeheid slechts een relatief begrip. De afgelopen twintig jaar was er sprake van een sterke toename van het aantal uitgezette korte en lange enquêtes. Omdat er steeds meer mogelijk is op technisch gebied is het tegenwoordig vrij eenvoudig om via e-mail bijvoorbeeld een zelfontwikkelde internetvragenlijst uit te zetten hetgeen dan ook veelvuldig gebeurt. Mensen worden tegenwoordig dus steeds vaker gevraagd om mee te doen aan een al dan niet professioneel opgezette enquête. Indien de gemiddelde burger 15 jaar geleden 5 vragenlijsten per jaar invulde en dat nu nog steeds doet kan hij of zij dus niet echt 'enquête moe' genoemd worden. Dat neemt niet weg dat de toename van het aantal uitgezette enquête-onderzoeken waarschijnlijk een dalend effect heeft gehad op de respons van de schoolverlatersonderzoeken.

\footnotetext{
${ }^{10}$ Bron: DUO en Vereniging Hogescholen

${ }^{11}$ West-Nederland: Provincies Noord-Holland, Zuid-Holland, Utrecht en Zeeland. Voor het hbo is dit gebaseerd op de provincie waar de hogeschool gevestigd is, voor de overige onderwijsniveaus is dit gebaseerd op de woonplaats tijdens het studiejaar 2011/2012.

12 Zie Hox en De Leeuw (2002).

${ }^{13}$ Zie Dillman, Smyth en Christian (2014)
} 
Figuur 3.1 Respons ROA schoolverlatersonderzoeken 2004-2013 ${ }^{14}$

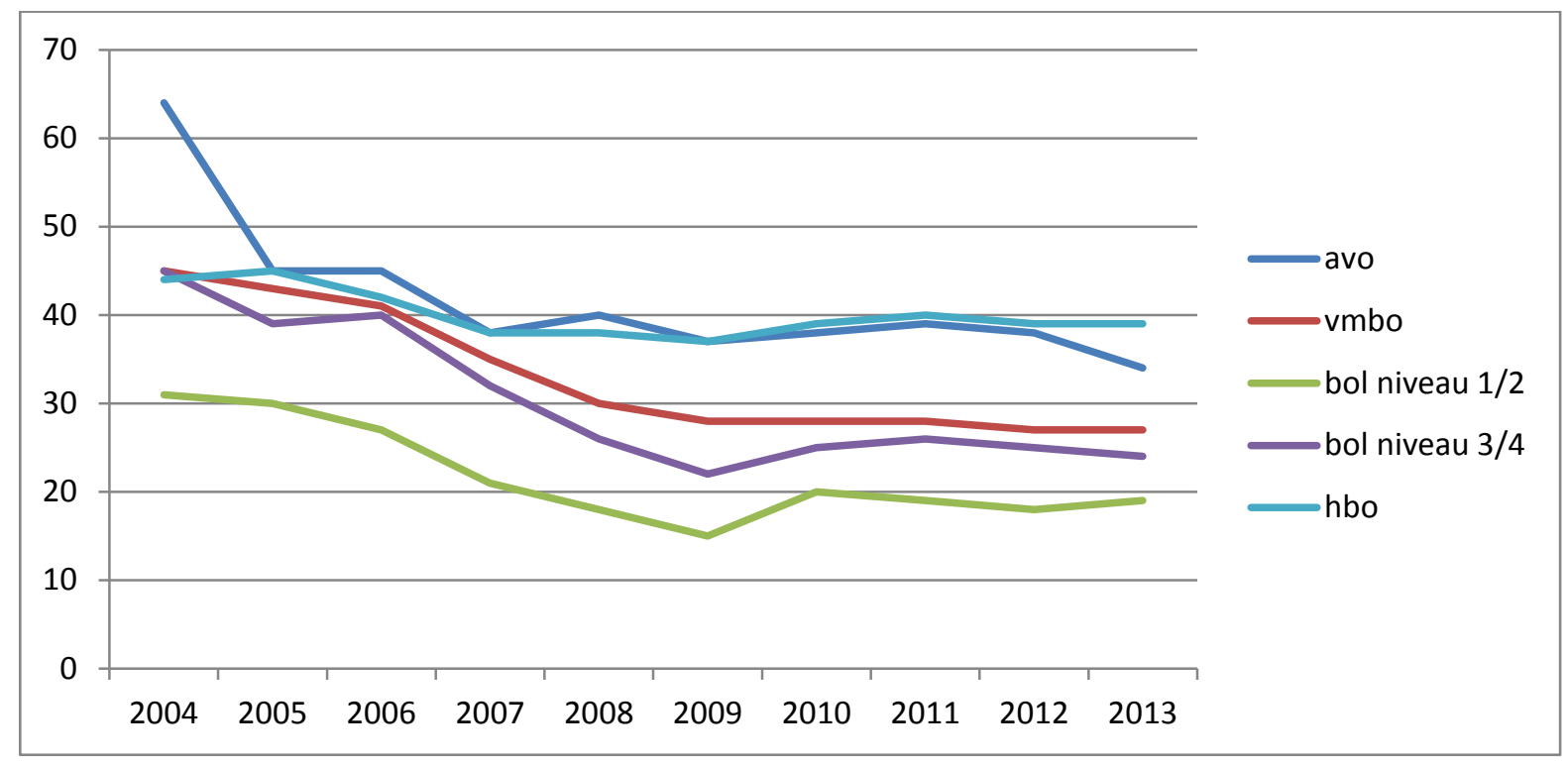

\subsubsection{De invloed van enquête- en persoonsgebonden kenmerken op de respons}

Of er nu wel of niet sprake is van enquêtemoeheid, er blijft bij survey-onderzoek altijd sprake van een groep mensen die het besluit neemt deel te nemen aan het onderzoek (respons) en een groep mensen die besluit niet deel te nemen (non-respons). ${ }^{15}$ Non-respons wordt door een aantal factoren beïnvloed. Zo zijn er in eerste instantie factoren die te maken hebben met de uitvoering van het onderzoek zelf, zogenaamde enquête-gebonden factoren. Zo is bijvoorbeeld de lengte van de vragenlijst van invloed, hoe langer de vragenlijst hoe minder snel men deelneemt. De methode van enquêtering is eveneens van invloed op de bereidwilligheid deel te nemen. Face-to-face interviews kennen een hogere respons dan bijvoorbeeld een internetenquête. De manier waarop mensen benaderd worden (telefonisch, schriftelijk, via e-mail of persoonlijk aangesproken) en het aantal keren dat men benaderd wordt is eveneens van invloed. Daarnaast is het onderwerp en de opdrachtgever van het onderzoek van invloed op de deelname. Zo zijn bijvoorbeeld onderwerpen als gezondheid, milieu en de woningmarkt in Nederland meer in trek dan onderwerpen als inkomen en politiek. ${ }^{16}$ Ook van invloed is de tegenprestatie: krijgt men feedback naar aanleiding van de enquête of staat er een financiële vergoeding tegenover?

Naast deze enquêtekenmerken spelen ook persoonsgebonden kenmerken een rol bij de respons. Zo responderen mannen vaak minder dan vrouwen en zijn mensen met een hoog opleidingsniveau vaker bereid mee te werken dan lager opgeleiden. De respons van mensen die in stedelijke gebieden woonachtig zijn ligt daarnaast vaak lager dan de respons van mensen die in landelijk gebieden woonachtig zijn en mensen die in een appartementencomplex wonen responderen minder vaak dan

\footnotetext{
${ }^{14}$ Het betreft de responscijfers van gediplomeerden van het voltijd onderwijs.

15 Non-respons kan feitelijk bestaan uit zowel personen die niet bereikt worden vanwege bijvoorbeeld verkeerde adressering of het niet thuis aanwezig zijn, personen die wel bereikt worden maar toch de enquête niet invullen omdat ze dat niet kunnen (bijvoorbeeld vanwege ziekte) en personen die bereikt worden maar weigeren mee te werken. Bij de ROA schoolverlatersonderzoeken is dit onderscheid vrijwel niet te maken en zal non-respons vanwege het niet mee willen werken, de laatste categorie, verreweg de grootste groep zijn van de totale non respons.

${ }^{16}$ Zie Stoop (2005).
} 
mensen die in een eengezinswoning wonen. ${ }^{17}$ Ook de leeftijd van de respondenten kan een rol spelen: ouderen responderen doorgaans vaker dan jongere mensen. De sociaal economische status van mensen (SES) is eveneens van invloed: hoe lager de SES hoe lager de bereidheid mee te werken aan survey onderzoek. Een ander veel onderzocht achtergrondkenmerk is de etniciteit van de benaderden: niet-westerse allochtonen responderen doorgaans minder vaak dan allochtone burgers.

Onderzoek toont echter aan dat de effecten van al deze persoonsgebonden factoren geenszins eenduidig zijn. Leeftijd speelt weliswaar een rol maar binnen de leeftijdsklassen is er sprake van responsverschillen, zeker als men kijkt naar specifieke enquête-onderwerpen. ${ }^{18}$ Etniciteit is een factor die in survey onderzoek een veel onderzocht achtergrondkenmerk is met verschillende conclusies tot gevolg. ${ }^{19}$ Het lijkt er op dat een persoonsgebonden achtergrondmerk op zichzelf niet eenduidig verklarend is voor een hogere of lagere respons maar dat er eerder sprake is van een combinatie van samenhangende factoren die een analyse lastig maken. Zo wonen niet-westerse allochtonen vaker in stedelijke gebieden en hebben zij vaak een wat lager opleidingsniveau dan autochtonen. Daarnaast blijkt de mate waarin survey onderwerpen gevoelig liggen sterk afhankelijk van de culturele achtergrond van personen. Persoonsgebonden achtergrondkenmerken zijn met andere woorden meestal niet direct de verklaring voor responsbereidheid, maar wel een indicatie voor onderliggende indirecte factoren zoals persoonlijke voorkeuren, sociale participatie en politieke betrokkenheid.

\subsubsection{Het gevaar van selectieve non-respons}

Het uitvoeren van een survey onderzoek is meestal een kostbare aangelegenheid en voor die reden alleen al wil men graag de respons zo hoog mogelijk houden. Een hogere respons betekent dat er meer cases in het uiteindelijke onderzoeksbestand terecht komen wat vervolgens weer betekent dat er meer onderzoeksmogelijkheden zijn. Wanneer men met een vooraf vastgesteld aantal respondenten voldoende informatie voor de onderzoeksdoeleinden heeft, betekent dit dat men niet noodzakelijk het hoogst mogelijke respons dient te behalen.

Wanneer het responsaantal aan een minimumeis voldoet, hoeft een laag responscijfer niet noodzakelijkerwijs te leiden tot verkeerde conclusies. Zoals in paragraaf 1.1. reeds werd vermeld, vormt een laag responscijfer pas een probleem wanneer de non-respons selectief is waardoor bepaalde respondentengroepen onder- of oververtegenwoordigd raken in het onderzoek. Indien in dit geval de ondervertegenwoordigde respondentengroepen op voor het onderzoek belangrijke kenmerken afwijken van de andere groepen kan dit leiden tot vertekeningen in de uitkomsten. $\mathrm{Er}$ is dan sprake van een selectieve non-respons. Bij de schoolverlatersonderzoeken hangen de persoonsgebonden achtergrondkenmerken opleidingsniveau of etniciteit vaak samen met selectieve non-respons. Al naar gelang deze selectieve non-respons 'missing at random' of 'not missing at random' is kan dit probleem worden opgelost. Bij zogenaamde 'missing at random' non-respons respondeert een groep weliswaar minder (bijvoorbeeld niet-westerse allochtonen) maar is er geen verschil tussen de niet responderende groep niet-westerse allochtonen en de groep responderende niet-westerse allochtonen. Door middel van oversampling bij het trekken van de steekproef of door middel van een weging na het veldwerk zou het probleem van selectieve non-respons (deels) kunnen worden opgelost. In het geval van 'not missing at random' selectieve non-respons wijkt de niet

\footnotetext{
${ }^{17}$ Zie Te Riele (2002).

${ }^{18}$ Zie Carlier e.a. (2007).

${ }^{19}$ Zie Sykes and Walker (2010).
} 
responderende groep op voor het onderzoek belangrijke factoren af van de responderende groep. Hierdoor ontstaat een informatiegebrek over de groep non-respondenten dat niet door middel van steekproeftrekking aanpassingen of met een weging kan worden opgelost. ${ }^{20}$

Het is kortom van belang om bij het eigen survey onderzoek zo goed als mogelijk zicht te hebben op mogelijke 'lastige' responsgroepen. In de volgende paragraaf wordt voor enkele achtergrondkenmerken nader bekeken of ze van invloed zijn op de respons bij de schoolverlatersonderzoeken uit meetjaar 2013.

\subsection{Responsanalyse}

In dit hoofdstuk wordt een onderscheid gemaakt tussen respons en non-respons. Hierbij is het van belang op te merken dat het er om gaat te analyseren of bepaalde kenmerken van invloed zijn op de kans dat iemand meedoet aan het onderzoek, door een vragenlijst in te vullen, of niet meedoet aan het onderzoek. Omdat mensen hoofdzakelijk via post en soms via e-mail benaderd worden is het vrijwel niet na te gaan of iemand weigert mee te doen of helemaal niet bereikt wordt. Slechts een klein deel van de brieven komt onbestelbaar retour terug maar dat wil uiteraard niet zeggen dat de rest ook bij de goede personen terecht komt. Bij andere methoden van onderzoek zoals telefonische enquêtes en face-to-face onderzoeken kunnen de redenen van non-respons explicieter worden geregistreerd. In het kader van de analyses in dit hoofdstuk verstaan we onder respons dan ook alle vragenlijsten die hetzij via internet hetzij schriftelijk retour worden gezonden. De non-respons bestaat dus zowel uit mensen die niet mee willen werken als uit mensen die niet bereikt zijn. Een case die aangemerkt wordt als respons hoeft overigens niet noodzakelijkerwijs in de onderzoeksbestanden terecht te komen. Deze kan alsnog buiten de data gelaten worden omdat hij niet aan de criteria voldoet (bijvoorbeeld vanwege de leeftijd van de respondent). Deze cases worden hier echter wel als respons beschouwd omdat men wel gereageerd heeft. In Tabel 3.1 staan de responscijfers van de schoolverlatersonderzoeken meetjaar 2013 verdeeld naar enkele achtergrondkenmerken (zie ook Bijlage 2 voor meer gedetailleerde cijfers).

Tabel 3.1 Respons meetjaar 2013 naar achtergrondvariabelen

\begin{tabular}{|c|c|c|c|c|c|}
\hline & & Respons \% & & & Respons \% \\
\hline Totaal & & 25,7 & & & \\
\hline \multirow[t]{2}{*}{ Geslacht $^{21}$} & man & 17,3 & Regio & West-Nederland & 24,8 \\
\hline & vrouw & 24,9 & & Nederland overig & 26,4 \\
\hline \multirow[t]{4}{*}{ Etniciteit $^{22}$} & westerse allochtoon & 18,4 & Onderwijssector & algemeen & 28,4 \\
\hline & niet-westerse allochtoon & 15,7 & & landbouw & 24,1 \\
\hline & autochtoon & 22,5 & & onderwijs & 41,4 \\
\hline & & & & techniek & 21,5 \\
\hline \multirow[t]{5}{*}{ Onderwijstype } & vmbo & 26,8 & & economie & 23,8 \\
\hline & avo & 33,6 & & gezondheidszorg & 27,4 \\
\hline & mbo & 20,7 & & gedrag en maatschappij & 30 \\
\hline & hbo & 39,7 & & kunst, taal en cultuur & 40,4 \\
\hline & ongediplomeerd & 17 & & & \\
\hline & & & & & \\
\hline
\end{tabular}

\footnotetext{
${ }^{20}$ In de literatuur wordt ook nog gesproken over de categorie 'missing completely at random' wat voor de minste problemen zorgt maar helaas ook maar zelden voorkomt.

${ }^{21}$ Exclusief hbo afgestudeerden

${ }^{22}$ Exclusief hbo afgestudeerden
} 
Uit de tabel blijkt dat iets meer dan een kwart van de benaderde personen gereageerd heeft. Daarnaast is de respons onder vrouwen hoger dan onder mannen en lijken met name niet-westerse allochtonen minder vaak te responderen dan autochtone schoolverlaters. De respons neemt toe naarmate het behaalde opleidingsniveau hoger is. Uit de responscijfers per sector blijkt dat de afgestudeerden met een technische opleidingsachtergrond minder vaak responderen dan de afgestudeerden van de andere onderwijssectoren. De sectorcijfers zijn onderling echter niet helemaal te vergelijken omdat niet alle onderwijstypes in alle sectoren vertegenwoordigd zijn. De sector onderwijs bestaat bijvoorbeeld uit alleen hbo afgestudeerden, terwijl in de sector economie zowel vmbo-, mbo- als hbo-gediplomeerden zitten.

Omdat veel factoren zoals etniciteit, regio en onderwijsniveau met elkaar samenhangen is met een logistische regressieanalyse geprobeerd de onderliggende invloeden enigszins uit elkaar te halen. Tabel 3.2 laat voor een eenvoudig en een uitgebreid model zien wat de resultaten zijn. Als basis voor beide modellen is gebruik gemaakt van data van de VO- en BVE monitoren. De paar scholen die zelf de adressen hebben aangeleverd en waarvan de schoolverlaters dus niet op basis van de bestanden van DUO benaderd werden, zijn uit de analyses gelaten. Dit omdat van de non-respondenten geen informatie over de achtergrondkenmerken beschikbaar is. Om dezelfde redenen zijn de afgestudeerden van het hbo niet in deze analyses meegenomen.

Tabel 3.2 Achtergrondkenmerken en kans op responderen

\begin{tabular}{|c|c|c|c|c|}
\hline & \multicolumn{2}{|c|}{ Model 1} & \multicolumn{2}{|c|}{ Model 2} \\
\hline Constante & $-1.629 * * *$ & $(0.016)$ & -1.517 & $(0.035)$ \\
\hline \multicolumn{5}{|l|}{ Onderwijsniveau } \\
\hline mbo niveau $1 / 2$ & ref. & & ref. & \\
\hline avo & $0.906 * * *$ & (0.039) & $0.712 * * *$ & $(0.061)$ \\
\hline vmbo & $0.507^{* * *}$ & $(0.027)$ & $0.468 * * *$ & $(0.035)$ \\
\hline bol niveau $1 / 2$ & $0.144^{* * *}$ & $(0.023)$ & $0.172 * * *$ & $(0.024)$ \\
\hline mbo niveau3/4 & $0.213^{* * *}$ & $(0.021)$ & $0.111^{* * *}$ & $(0.022)$ \\
\hline bol niveau $3 / 4$ & $0.221^{* * *}$ & $(0.017)$ & $0.253^{* * *}$ & $(0.017)$ \\
\hline \multicolumn{5}{|l|}{ Onderwijssector } \\
\hline gezondheidszorg & & & ref. & \\
\hline algemeen & & & $0.103^{*}$ & $(0.048)$ \\
\hline landbouw & & & $-0.113 * * *$ & $(0.03)$ \\
\hline techniek & & & -0.035 & $(0.021)$ \\
\hline economie & & & $-0.111 * * *$ & $(0.018)$ \\
\hline gedrag en maatschappij & & & -0.013 & $(0.022)$ \\
\hline \multicolumn{5}{|l|}{ Geslacht } \\
\hline man & & & $-0.407 * * *$ & $(0.014)$ \\
\hline \multicolumn{5}{|l|}{ Diplomabezit } \\
\hline Diploma & & & $0.320 * * *$ & $(0.028)$ \\
\hline \multicolumn{5}{|l|}{ Regio } \\
\hline West & & & $-0.062 * * *$ & $(0.012)$ \\
\hline \multicolumn{5}{|l|}{ Etniciteit } \\
\hline autochtoon & & & ref. & \\
\hline
\end{tabular}




\begin{tabular}{|l|l|l|l|l|}
\hline & \multicolumn{2}{|c|}{ Model 1 } & \multicolumn{2}{c|}{ Model 2 } \\
\hline westerse allochtoon & & & $-0.249^{* * *}$ & $(0.027)$ \\
\hline niet-westerse allochtoon & & & $-0.442^{* * *}$ & $(0.018)$ \\
\hline & & & & \\
\hline $\mathrm{N}=$ & 171442 & & 170758 & \\
\hline & & & & \\
\hline
\end{tabular}

$* p<0.05, * * p<0.01, * * * p<0,001$

In model 1 is gekeken naar wat de invloed is van het onderwijsniveau op de respons. Alhoewel de effecten niet heel groot zijn blijkt dat avo schoolverlaters een hogere kans op responderen hebben dan de afgestudeerden van de andere onderwijsniveaus. ${ }^{23}$ Mbo niveau 3 en 4 schoolverlaters responderen beter dan hun mbo collega's van de niveau 1 en 2 opleidingen. Ten opzichte van de bol is de kans op responderen onder de bbl'ers lager. In model 2 worden meerdere kenmerken in de analyse betrokken. Behalve naar het onderwijsniveau is ook het geslacht, de onderwijssector, de etniciteit, het diplomabezit en de regio in de analyse betrokken. Alhoewel de coëfficiënten wat wijzigen blijven de conclusies met betrekking tot het gevolgde onderwijsniveau en de kans op responderen bij dit model hetzelfde. Verder blijkt dat de kans op responderen bij afgestudeerden uit de sectoren economie en landbouw significant lager is dan onder afgestudeerden met een opleiding uit de sector gezondheidszorg. De kans op respons is daarnaast lager bij het mannelijke deel van de steekproef en bij de voortijdig schoolverlaters. Uit onderzoek komt vaak naar voren dat de respons in verstedelijkte gebieden lager is dan in de meer landelijke gebieden (zie ook hoofdstuk 2). Alhoewel er in deze analyse slechts onderscheid gemaakt is tussen West-Nederland versus de rest van Nederland lijkt ook hier dat de kans op responderen in het meer verstedelijkte westen iets lager is dan in de rest van Nederland.

De responskans onder allochtonen is significant lager dan onder autochtonen, met name de nietwesterse allochtonen responderen minder. Ondanks dat er gecontroleerd wordt voor enkele andere achtergrondkenmerken lijken niet-westerse allochtonen minder vaak geneigd om aan de enquête deel te nemen. Een in de wetenschappelijke literatuur veel genoemde hiermee samenhangende variabele is de Sociaal Economische Status (SES) van de benaderden die voor een deel van de hogere non-respons kans onder allochtonen verantwoordelijk zou zijn. SES heeft betrekking op de sociale gelaagdheid en wordt vaak gemeten aan de hand van opleidingsniveau, beroepsstatus en inkomen. Omdat niet al deze kenmerken voor de non-respondenten bekend zijn kan deze SES indicator niet in de analyse meegenomen worden.

De meeste coëfficiënten in Tabel 3.2 zijn (zeer) significant. Hierbij dient opgemerkt te worden dat de meeste effecten slechts klein zijn. Dat deze geringe verschillen toch vaak significant zijn, wordt met name veroorzaakt door het hoge aantal cases $(\mathrm{N})$ dat in de regressie opgenomen is.

\section{Het effect van het toevoegen van een schriftelijke vragenlijst}

\subsection{Inleiding}

Een enquête kan via verschillende methoden worden afgenomen. Het geven van zoveel mogelijk opties om de enquête in te vullen is vanuit de respondent gezien een stimulans om eerder mee te doen aan het onderzoek. ledereen kan dan via zijn of haar methode van voorkeur deelnemen

\footnotetext{
${ }^{23}$ Een vergelijkbare regressie inclusief de hbo afgestudeerden toont dat de kans op responderen bij de hbo'ers hoger is dan bij de andere onderwijsniveaus.
} 
hetgeen de drempel tot deelname verlaagt. Het gebruik maken van verschillende interviewmodes kan echter ook een verlies aan kwaliteit betekenen. Dit omdat er tussen de verschillende methoden van enquêteren weer verschillen kunnen ontstaan tussen de vragen of de interpretatie en/of de invulbaarheid van vragen. ${ }^{24}$ Zo kunnen niet alle vragen van een schriftelijke vragenlijst telefonisch afgehandeld worden of kunnen vragen via internet anders geïnterpreteerd worden dan via een schriftelijke variant. Zo zal het aantal antwoordcategorieën waar een respondent uit kan kiezen bij telefonische vragenlijsten beperkt moeten blijven. Deze worden immers opgelezen door de interviewer en kunnen maar in beperkte mate door de respondent onthouden en meegenomen worden bij de beantwoording van de vraag. Bij schriftelijke vragenlijsten en vragenlijsten via internet ziet de respondent de antwoordencategorieën voor zich hetgeen zijn keuzeproces bij het antwoorden van de vraag vereenvoudigd. Bij vragenlijsten via internet is er technisch gezien veel meer mogelijk om respondenten door de vragenlijst te leiden dan bij schriftelijke vragenlijsten. Denk hierbij aan verwijzingsstructuren en het gebruiken van eerder in de enquête gegeven antwoorden bij vervolgvragen. Zo wordt bij internetvragenlijst vaak per scherm maar 1, of een heel beperkt aantal vragen gepresenteerd hetgeen bij schriftelijke vragenlijsten niet gebeurt. Dit kan leiden tot kleine verschillen in de spreiding van de antwoorden. ${ }^{25} \mathrm{Er}$ is in dit opzicht dus een evenwicht tussen het alsmaar proberen de respons te verhogen en het mogelijke verlies aan datakwaliteit.

Bij de ROA schoolverlatersonderzoeken wordt met name gebruik gemaakt van schriftelijke vragenlijsten en vragenlijsten die via een webapplicatie ingevuld kunnen worden. Uit Tabel 2.1 in hoofdstuk twee blijkt dat met name bij de wat lagere onderwijsniveaus er toch nog redelijk vaak gebruikt wordt gemaakt van schriftelijke vragenlijsten door respondenten. Het onder druk staan van responspercentages is de hoofdreden voor het gebruik van deze schriftelijke varianten maar de kosten er van zijn redelijk hoog. Niet alleen de druk- en portokosten, maar ook de verwerkingskosten liggen hoger bij schriftelijke vragenlijsten. Het zou vanwege deze kosten en de bewerkelijkheid van schriftelijke vragenlijsten de voorkeur hebben om ze niet meer te gebruiken. De vraag is echter hoe hoog de respons zou zijn indien er geen gebruik wordt gemaakt van schriftelijke vragenlijstenvarianten. Daarnaast is het vooralsnog onduidelijk of de groep die via internet respondeert op belangrijke kenmerken afwijkt van de groep die de vragenlijst schriftelijk retourneert. Het aanbieden van alleen een internetvragenlijst in plaats van zowel een internet- als een schriftelijke vragenlijst kan dan namelijk leiden tot selectieve respons. In geval de voorheen schriftelijke respondenten afwijken van de internetrespondenten en bij het wegvallen van de schriftelijke vragenlijst niet of minder gaan responderen zal de selectiviteit van de responsgroep toenemen. Vanwege een uitbreiding van de steekproef in meting 2013 onder mbo gediplomeerden is het mogelijk om, tenminste voor de BVE-monitor, deze twee vragen nader te bekijken.

\subsection{Responseffect schriftelijke vragenlijst}

In meetjaar 2013 is er voor de mbo gediplomeerden in eerste instantie een aselecte steekproef getrokken onder de regulier deelnemende bve instellingen. Dit deel van de populatie had zoals gebruikelijk zowel de mogelijkheid om de vragenlijst schriftelijk als via internet in te vullen. In het kader van een ander project is later besloten dat de gehele mbo populatie benaderd moest worden. Als gevolg hiervan is het resterende deel van de mbo'ers die in eerste instantie niet in de aselecte steekproef vielen eveneens benaderd. Deze laatste groep heeft echter niet de mogelijkheid gehad

\footnotetext{
${ }^{24}$ Zie ook Biemer (2003)

${ }^{25}$ Zie Dillman, Smyth en Christian (2014)
} 
om een schriftelijke vragenlijst in te vullen maar had wel eenzelfde brief en precies dezelfde vragenlijst. Het enige verschil is dat bij de uitbreidingsgroep de eerste verzending een maand later is opgestart, 5 november 2013 tegenover 3 oktober bij de reguliere eerste aselecte steekproefgroep. Daarnaast zat er bij de uitbreidingsgroep 23 dagen tussen de eerste en de tweede zending en 18 dagen tussen de tweede en de derde. Bij de eerste groep, die bij de eerste aanschrijving dus ook een schriftelijke vragenlijst ontvangen heeft, was dit 28 en 21 dagen, dus iets meer.

Middels een regressieanalyse is gekeken of er een verschil is in de kans op responderen tussen de eerste groep en de tweede groep. Wanneer gecontroleerd wordt voor andere kenmerken als onderwijsniveau, -sector, regio, geslacht en etniciteit is de kans op responderen bij de tweede groep, d.w.z. de groep die geen schriftelijke vragenlijst heeft gehad, opvallend genoeg iets hoger dan bij de eerste groep. Het weglaten van de schriftelijke vragenlijst heeft met andere woorden geen negatief effect op de respons gehad. Respondenten die in eerste instantie een schriftelijke lijst invullen haken blijkbaar niet af als ze die mogelijkheid niet hebben en alleen de internetvariant kunnen invullen.

\subsection{Verschillen in samenstelling respondentgroepen internet versus schriftelijk}

Zelfs indien een kleine groep schriftelijke respondenten niet overgaat tot het invullen van de enquête via internet hoeft het afschaffen van de schriftelijke lijst niet direct tot vertekeningen van schattingen te leiden. In het geval beide groepen respondenten, de schriftelijke respondenten en de internetrespondenten, op voor het onderzoek belangrijke kenmerken niet verschillend zijn zal ook een enquête alleen via internet een evenzo representatieve respons opleveren. Om hier inzicht in te krijgen is gekeken wat de invloed is van het invullen van de vragenlijst via internet dan wel schriftelijk op een drietal indicatoren, te weten: (1) het aanbieden op de arbeidsmarkt, (2) werkloosheid en (3) het volgen van een vervolgopleiding. Voor de mbo respondenten die via DUO benaderd zijn, is daarom een onderscheid gemaakt tussen hen die bij de eerste aselecte steekproef via internet of schriftelijk gereageerd hebben. In Tabel 4.1 staan de resultaten van de genoemde analyses.

De kans dat een respondent zich aanbiedt op de arbeidsmarkt ${ }^{26}$ ligt onder de internetrespondenten iets lager dan onder de schriftelijke respondenten. Ook als rekening gehouden wordt met andere achtergrondkenmerken, is de kans dat een respondent zich aanbiedt op de arbeidsmarkt bij internetrespondenten significant kleiner. Dit effect is echter zeer klein (zie kolom 2 Tabel 4.1). Het eveneens significante effect van de bol versus de bbl respondenten is veel groter. Door de aard van het bbl-onderwijs biedt het overgrote deel van deze respondenten zich aan op de arbeidsmarkt.

\footnotetext{
${ }^{26}$ Dit aanbieden op de arbeidsmarkt is exclusief respondenten die zichzelf als 'studerend' zien. Het gaat dus om personen die de overstap van het onderwijs naar de arbeidsmarkt gedaan hebben en niet om studenten met bijbaantjes e.d.
} 
Tabel 4.1 Verschillen tussen internet en schriftelijke respondenten in kans op aanbieden op arbeidsmarkt, werkloosheid en vervolgonderwijs

\begin{tabular}{|c|c|c|c|c|c|c|}
\hline & \multicolumn{2}{|c|}{$\begin{array}{c}\text { Aanbieden op } \\
\text { arbeidsmarkt }\end{array}$} & \multicolumn{2}{|c|}{ Werkloosheid } & \multicolumn{2}{|c|}{ Vervolgonderwijs } \\
\hline & $b$ & $S D$ & $b$ & $S D$ & $b$ & $S D$ \\
\hline Constante & $3.402^{* * *}$ & (0.199) & $-2.782 * * *$ & $(0.22)$ & $-1.722 * * *$ & $(0.119)$ \\
\hline \multicolumn{7}{|l|}{ Enquêtevorm } \\
\hline Internet & $-0.319 * * *$ & $(0.069)$ & -0.075 & $(0.11)$ & $0.26 * * *$ & $(0.057)$ \\
\hline \multicolumn{7}{|l|}{ Onderwijsniveau } \\
\hline mbo niveau $1 / 2$ & ref. & & ref. & & ref. & \\
\hline bol niveau $1 / 2$ & $-2.909 * * *$ & $(0.193)$ & $1.5^{* * *}$ & $(0.216)$ & $1.667 * * *$ & (0.119) \\
\hline mbo niveau3/4 & $0.608^{*}$ & $(0.259)$ & $-0.623^{*}$ & $(0.251)$ & $-0.421 * *$ & $(0.128)$ \\
\hline bol niveau 3/4 & $-2.979 * * *$ & $(0.194)$ & $1.459 * * *$ & $(0.192)$ & $1.66 * * *$ & $(0.094)$ \\
\hline \multicolumn{7}{|l|}{ Onderwijssector } \\
\hline gezondheidszorg & ref. & & ref. & & ref. & \\
\hline landbouw & $-0.522 * * *$ & (0.113) & $0.649 * * *$ & $(0.177)$ & 0.072 & $(0.092)$ \\
\hline techniek & $-0.371 * *$ & $(0.123)$ & $0.477^{*}$ & $(0.203)$ & $0.591^{* * *}$ & $(0.099)$ \\
\hline economie & $-0.702 * * *$ & $(0.104)$ & $0.553 * *$ & $(0.164)$ & $0.64 * * *$ & $(0.084)$ \\
\hline gedrag en maatschappij & $-0.791 * * *$ & $(0.12)$ & $0.596 * *$ & $(0.191)$ & $0.395^{* * *}$ & $(0.098)$ \\
\hline \multicolumn{7}{|l|}{ Geslacht } \\
\hline man & 0.072 & $(0.079)$ & $-0.673 * * *$ & $(0.136)$ & $0.178 * *$ & $(0.066)$ \\
\hline \multicolumn{7}{|l|}{ Regio } \\
\hline West & $0.24 * *$ & $(0.075)$ & $-0.251^{*}$ & $(0.121)$ & $-0.191 * *$ & $(0.061)$ \\
\hline \multicolumn{7}{|l|}{ Etniciteit } \\
\hline autochtoon & ref. & & ref. & & ref. & \\
\hline westerse allochtoon & -0.252 & $(0.153)$ & $0.505^{*}$ & $(0.226)$ & -0.073 & $(0.13)$ \\
\hline niet-westerse allochtoon & $-0.661 * * *$ & $(0.108)$ & $1.182^{* * *}$ & $(0.162)$ & $0.213^{*}$ & $(0.092)$ \\
\hline $\mathrm{N}=$ & 5002 & & 3434 & & 6007 & \\
\hline & & & & & & \\
\hline
\end{tabular}

${ }^{*} p<0.05,{ }^{* *} p<0.01,{ }^{* * *} p<0,001$

Dit laatste is ook de reden van de vele lagere kans op werkloosheid onder de bbl respondenten. Uit kolom 4 van Tabel 4.1 blijkt dat de bol gediplomeerden een hogere kans op werkloosheid hebben dan hun bbl studiegenoten. Daarnaast blijkt dat niet-westerse allochtonen vaker werkloos zijn dan autochtonen. Tussen de internet- en de schriftelijke respondenten zijn echter geen verschillen in werkloosheid zichtbaar hetgeen suggereert dat het weglaten van de schriftelijke vragenlijst er in ieder geval niet toe zou leiden dat de werkloosheidscijfers zullen veranderen. De internetrespondenten beginnen na het behalen van het diploma ook iets vaker met een vervolgopleiding maar het effect is wederom klein. Bol gediplomeerden hebben ten opzichte van de bbl gediplomeerden een veel grotere kans op directe instroom in het vervolgonderwijs. 


\section{Vroege versus late respondenten}

\subsection{Inleiding}

Wanneer respondenten en non-respondenten verschillen in belangrijke achtergrondkenmerken (zoals behaald opleidingsniveau, etniciteit), kan er een vertekening in de schatting van de kernvariabelen ontstaan. Door selectiviteit van de non-respons kan het gebeuren dat de respondenten geen goede afspiegeling vormen van de populatie die ze zouden moeten vertegenwoordigen. Het uitvoeren van een apart onderzoek onder de non-respondenten zou hierin meer duidelijkheid kunnen scheppen maar deze onderzoeken zijn tijdrovend en kostbaar. Vooral omdat het om non-respondenten gaat, is de bereidwilligheid om mee te werken aan nonresponsonderzoek meestal laag en is de informatie die met dit soort onderzoek verzameld kan worden summier. Daarnaast is er bij non-responsonderzoek wederom sprake van non-respons en is een bepaalde mate van selectiviteit dus niet uit te sluiten. Bij de door het ROA gehouden schoolverlatersonderzoeken zijn de afgelopen jaren geen non-responsonderzoeken meer uitgevoerd.

Om toch iets te kunnen zeggen over deze non-respondenten, kan er gekeken worden of er een verschil is op belangrijke indicatoren tussen de zogenaamde vroege respondenten en de zogenaamde late respondenten. Om tot een zo hoog mogelijke respons te komen, volgen bij de meeste enquêtes na de eerste uitnodiging één of meerdere herinneringen. Dit, omdat sommige mensen al na één keer besluiten mee te doen met het onderzoek en er voor anderen meer overredingskracht, uitnodigingen nodig zijn voordat ze participeren. Dit 'Continuüm of Resistance'model gaat er van uit dat de eerste respondent graag meedoet aan onderzoek en de latere respondenten steeds meer overredingskracht nodig hebben ${ }^{27}$. Dat er uiteindelijk een groep overblijft die zelfs na oneindige aantallen herinneringen non-respondent zullen blijven, neemt niet weg dat een aanzienlijk deel van de mensen mee zal doen als er maar voldoende herinneringen verstuurd zullen worden. Het model gaat er van uit dat de late respondenten meer met de uiteindelijke nonrespondenten overeenkomen dan de vroege respondenten. In de praktijk is het aantal verstuurde herinneringen vanuit zowel ethisch als kostenoogpunt echter beperkt. Naarmate het aantal mailingen toeneemt zullen de kosten van het onderzoek duurder uitvallen. Het is daarnaast niet wenselijk om beoogde respondenten ongelimiteerd te blijven lastgvallen aangezien het een vrije keuze is om aan een enquête mee te doen. Te veel herinneringen zou het enquête-onderzoek in het algemeen maar zeker de opdrachtgevers en uitvoerders van het onderzoek een negatief imago bezorgen.

\subsection{Verschillen tussen vroege en late respondenten}

Om enig zicht te krijgen op de vraag of late respondenten eigenlijk wel verschillen van vroege respondenten hebben we onderzocht of er verschillen zijn tussen de mbo-gediplomeerden die meteen na de eerste mailing gereageerd hebben en mbo-gediplomeerden die pas na de eerste of tweede rappel gereageerd hebben. Dit zijn we nagegaan voor zowel de internetrespondenten van de initiële eerste mbo steekproef als de internetrespondenten van de uitbreiding van de mbo steekproef naar de totale populatie. Voor de schriftelijke respons hebben we dit niet nader onderzocht. Dit, omdat er door vertragingen in het retourneren van de vragenlijsten door respondenten en het scannen van batches in plaats van individuele binnengekomen vragenlijsten de link tussen datum binnenkomst en het aantal door de respondent ontvangen mailingen minder

\footnotetext{
${ }^{27}$ Zie ook Lin en Schaeffer (1995)
} 
eenduidig is. Hoewel de initiële steekproef en de uitbreiding beide via internet verlopen zijn, zijn er toch een aantal belangrijke verschillen tussen de twee steekproeven. Zo zijn allereerst de mailingen op een ander tijdstip verzonden aan beide groepen (zie ook paragraaf 4.2). Daarnaast hebben de respondenten van de initiële steekproef ook de mogelijkheid gehad om de vragenlijst schriftelijk te retourneren, hetgeen de internetrespondenten van deze groep een wat selectievere groep maakt dan de internetrespondenten van de uitbreidingsgroep die deze keuze niet hadden.

Figuren 5.1a tot en met 5.1d laten voor beide groepen de ontwikkeling zien in het percentage nietwesterse allochtonen (5.1a), het percentage mannen (5.1b), het percentage dat zich aanbiedt op de arbeidsmarkt (5.1c) en het percentage werklozen (5.1d). Op de horizontale as in de figuren staat de responssnelheid waarbij 1 staat voor respons die na de eerste mailing is binnengekomen en 3 voor de respons die pas na de derde mailing is binnengekomen.

Figuur 5.1a Percentage niet-westerse allochtonen naar responssnelheid

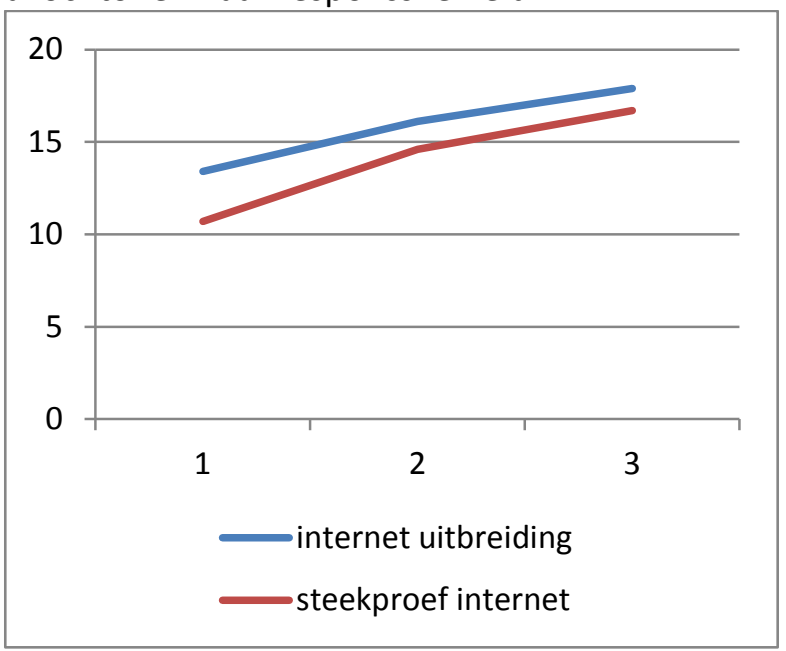

Figuur 5.1c Percentage aanbieders op de arbeidsmarkt naar responssnelheid

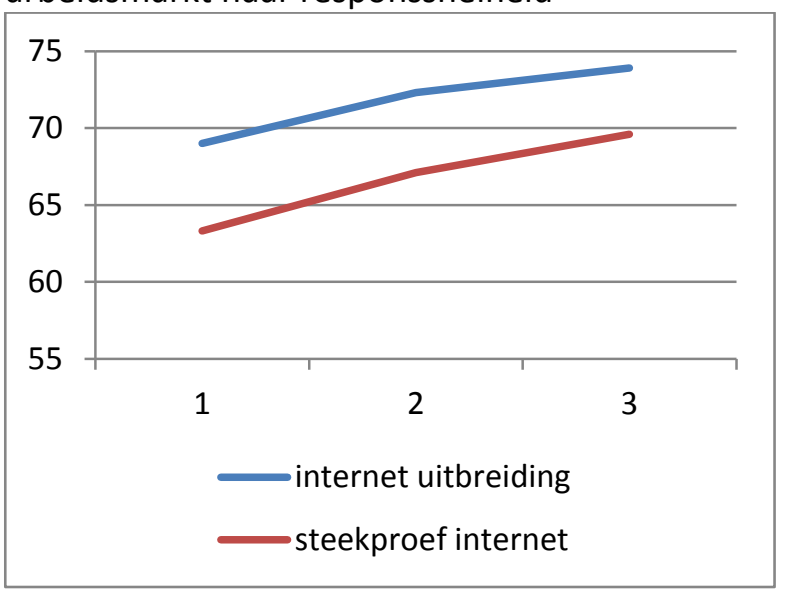

Figuur 5.1b Percentage mannen naar responssnelheid

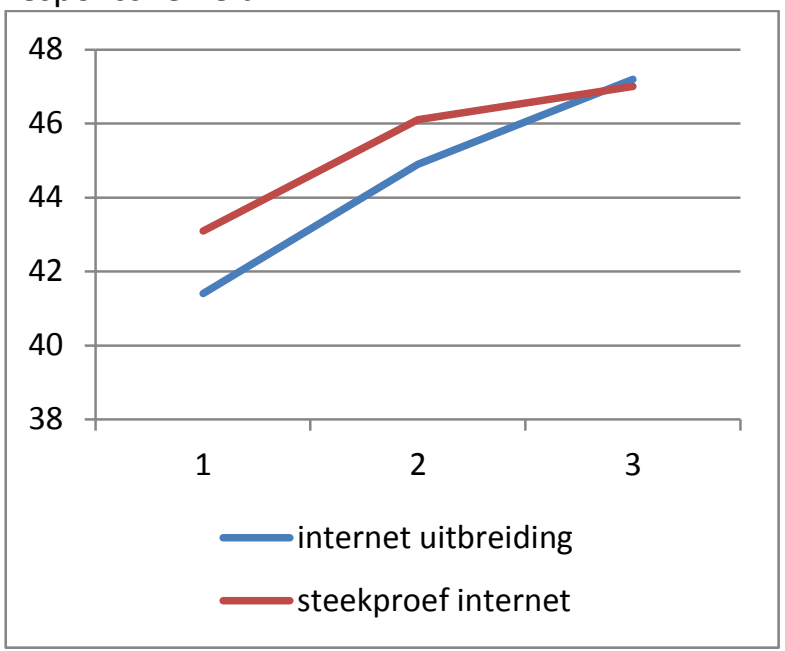

Figuur 5.1d Percentage werklozen naar responssnelheid

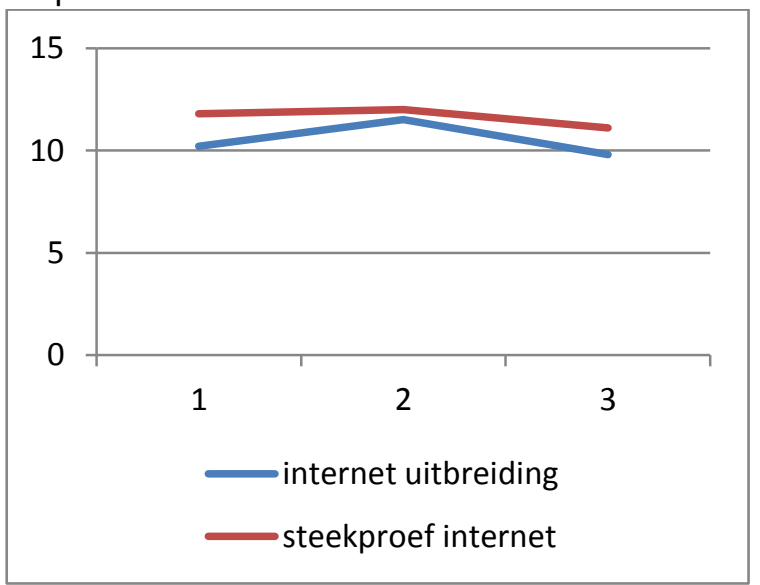

Uit de figuren 5.1 a tot en met 5.1d komen een aantal punten naar voren. Allereerst hebben zowel mannen als niet-westerse allochtonen een wat langere responstijd nodig, of anders gezegd: er zijn meerdere mailingen nodig om hen tot deelname te overtuigen dan bij vrouwen c.q. autochtonen. In de groep die pas na drie mailingen reageert, ligt zowel het percentage mannen als het percentage 
niet-westerse allochtonen aanzienlijk hoger dan in de groep die meteen na de eerste mailing gereageerd heeft. Het percentage schoolverlaters dat zich aanbiedt op de arbeidsmarkt is in de laatste groep ook hoger dan in de eerste groep (zie figuur 5.1c) hetgeen betekent dat werkenden wat minder snel responderen dan personen die naar het vervolgonderwijs zijn gegaan of geen van beide kanten op zijn gegaan. Er lijken geen werkloosheidsverschillen te zijn tussen de vroege en late respondenten. De beide lijnen in de figuren 5.1a tot en met 5.1d tonen dezelfde ontwikkeling hetgeen inhoudt dat de verschillen tussen de vroege en late respondenten zich voor beide groepen hetzelfde manifesteren. De beide groepen zijn echter niet helemaal met elkaar te vergelijken, hierdoor liggen de lijnen ook niet op precies dezelfde hoogte, omdat de steekproef respondenten ook de mogelijkheid gehad hebben om de schriftelijke vragenlijst in te vullen. Hierdoor bestaat deze groep zoals eerder vermeld uit een wat selectievere groep dan de groep die alleen de internet variant als enquêtemogelijkheid had.

Middels een logistische regressieanalyse is gekeken hoe bovenstaande vier factoren samenhangen met de kans dat men in periode 3 respondeert. Hieruit blijkt dat de kenmerken 'aanbieden op de arbeidsmarkt' en 'niet-westerse etniciteit' inderdaad significant samenhangen met de kans dat men in periode 3 gerespondeerd heeft. Hierbij is gecontroleerd voor andere variabelen zoals regio, opleidingsniveau en opleidingsrichting. Het feit dat men van het mannelijke geslacht is of werkloos is of niet heeft geen significant effect.

Dit alles betekent dat de samenstelling van de responsgroep iets anders zou zijn geweest indien er na twee in plaats van drie mailingen, gestopt zou worden met het veldwerk. Dit, omdat de samenstelling van de groep respondenten na drie mailingen iets afwijkt van de samenstelling van de groepen respondenten na één respectievelijk twee mailingen. In absolute zin zijn de verschillen over het totaal echter wat minder groot dan uit de figuren 5.1a tot en met 5.1d lijken. Dit komt doordat de bulk van de respons in aantallen respondenten in het begin van de veldwerkperiode zit en de lagere aantallen respondenten die laat reageren in absolute zin wat minder gewicht in de schaal leggen. Voor de schoolverlatersonderzoeken is het echter wel van belang met betrekking tot trendbreuken dat met deze lichte vertekening rekening gehouden wordt en het veldwerk wat aantallen contactmomenten met de steekproef gelijk gehouden wordt. Het werkloosheidspercentage is weliswaar bij de eerste respondenten niet afwijkend van dat van de latere respondenten maar er is wel sprake van bijvoorbeeld een lager percentage niet-westerse allochtonen onder de vroege respondenten.

Wanneer uitgegaan wordt van het eerder genoemde 'Continuüm of Resistance'-model betekent dit dat de late respondenten dus iets meer de kenmerken van de non-responsgroep benaderen dan de vroege respondenten. Voor het schoolverlatersonderzoek betekent dit verder ook dat de nonrespondenten dus iets vaker van niet-westerse afkomst zijn en zich iets vaker op de arbeidsmarkt aanbieden dan de respondenten. Om dit helemaal zeker te weten zou echter een specifiek nonrespons onderzoek nodig zijn. Positief is dat de late respondenten in ieder geval niet op een voor het onderzoek belangrijke variabele als werkloosheid afwijken van vroege respondenten. Volgens het genoemde model zouden de non-respondenten dan waarschijnlijk ook niet minder of meer werkloosheid kennen dan de respondenten. 


\section{Conclusies}

Op basis van responsanalyses is in dit document getracht inzicht te geven op enkele vragen rondom de selectiviteit van de respons bij de jaarlijkse ROA schoolverlatersonderzoeken. Hierbij ging het om de volgende vragen:

Wat is de invloed van bepaalde achtergrondkenmerken op de respons?

De gediplomeerden van de mbo-bbl leerweg hebben een significant lagere respons dan gediplomeerden van de mbo-bol leerweg. Daarnaast daalt de respons naarmate het gevolgde opleidingsniveau afneemt. Mannen responderen minder dan vrouwen en niet-westerse allochtonen hebben een lagere kans op responderen dan de autochtonen. Ook het diplomabezit is van invloed: de voortijdig schoolverlaters responderen minder dan de gediplomeerden.

Wat is de invloed van het meesturen van een papieren vragenlijst op de respons?

Wanneer gecontroleerd wordt voor kenmerken als onderwijsniveau, -sector, regio, geslacht en etniciteit is er geen effect te vinden van het meesturen van een schriftelijke vragenlijst op de respons. Respondenten die in eerste instantie een schriftelijke lijst invullen haken blijkbaar niet af als ze die mogelijkheid niet hebben en alleen de internetvariant kunnen invullen. Wel is er een klein verschil tussen de schriftelijke respondenten en de internetrespondenten: de internetrespondenten bieden zich iets minder vaak aan op de arbeidsmarkt en stromen iets vaker door naar een vervolgopleiding. Er is echter geen verschil in werkloosheidspercentages tussen beide groepen.

Is er een verschil tussen de 'vroege' en 'late' respondenten?

Onder de late respondenten bevinden zich relatief meer niet-westerse allochtonen en relatief meer mensen die zich op de arbeidsmarkt aanbieden. Late respondenten zijn echter niet meer of minder werkloos dan de vroege respondenten.

Moet er naar aanleiding van de antwoorden op bovengenoemde vragen iets aan de onderzoeksopzet van de ROA schoolverlatersonderzoeken veranderd worden?

Gezien het verschil in samenstelling tussen de vroege en late respondentgroepen is het niet mogelijk om het aantal verzendingen verder in te perken. Met name omdat niet-westerse allochtonen wat minder responderen zijn deze drie benaderingspogingen noodzakelijk. Binnen het mbo zou echter wel overwogen kunnen worden de schriftelijke vragenlijst achterwege te laten. De kostenbesparingen die hiermee gepaard gaan zouden besteed kunnen worden aan het meer gediversifieerd benaderen van de verschillende groepen. Tijdens het veldwerk zou bijvoorbeeld een onderscheid in de benaderingsstrategieën gemaakt kunnen worden als het gaat om moeilijkere groepen zoals de bbl-gediplomeerden, niveau 1-gediplomeerden en niet-westerse allochtonen. Vanwege de huidige onderzoeksopzet en het feit dat het veldwerk ook in samenwerking met DUO en een verzendhuis plaatsvindt, betekent dit wel dat er organisatorisch weer een aantal nadelen aan verbonden zijn. Er zijn echter op korte termijn geen redenen om grote wijzigingen in de huidige opzet aan te brengen.

Een ander belangrijk punt dat in dit document verder niet besproken is zijn de selectiviteits - en andere kwesties rondom item non-respons. Om het in kaart brengen van het selectiviteitsprobleem 
rondom de ROA schoolverlatersonderzoeken af te maken zou een nadere verkenning van de item non-respons van groot belang zijn. Vragen die hierbij aan de orde kunnen komen zijn: in hoeverre passen de vragen wat moeilijkheidsgraad betreft bij de doelgroepen? Zijn er verschillen in de wijze waarop vragen worden ingevuld als het gaat om internet versus schriftelijk? Zijn er vragen die wat gevoeligheid betreft verschillen tussen de diverse bevolkingsgroepen? En: Zijn er verschillen in invullen tussen vroege en late respondenten? 


\section{Literatuur}

American Association for Public Opinion Research. 2011. Standard Definitions: Final Dispositions of Case Codes and Outcome Rates for Surveys. 7th edition. AAPOR.

Bethlehem, J., Weging als correctie voor non-respons, CBS Statistische Methodenreeks (08005)

Biemer, Paul P., and Lars E Lyberg, Introduction to Survey Quality, Wiley, New Jersey, 2003

Dillman, Don A., Smyth, Jolene D. and Leah Melani Christian, Internet, Phone, Mail and Mixed-Mode Surveys, The Tailored Design Method, $4^{\text {th }}$ edition, Wiley, New Jersey, 2014

Feskens, R.C.W., J.J. Hox, G.J.L.M. Lensvelt-Mulders en J.J.G. Schmeets (2007). Nonresponse among ethnic minorities: A multivariate analysis. In: Journal of Official Statistics, jg. 23, nr. 3, p. 387-408.

GG\&GD Utrecht, Enquêteonderzoek onder achterstandsgroepen: non-respons en interne validiteit, Utrecht, Februari 2007

Groves, Robert M., and Mick P. Couper (1989), Nonresponse in Household Surveys, New York: Wiley

Hox, Joop, and Edith de Leeuw (2002) The Influence of Interviewers' Attitude and Behavior on Household Survey Nonresponse: An International Comparison. In: Robert M. Groves, Don A. Dillman, John L. Eltinge and Roderick J.A. Little (eds.) Survey nonresponse. New York: Wiley, pp. 103-120

Leeuw de, Edith D., Hox, Joop J., en Don A. Dillman, International Handbook of Survey Methodology, Lawrence Erlbaum Associates, New York, 2008

Lin, I-Fen, en Nora Cate Schaeffer (1995) Using Survey Participants to Estimate the Impact of Nonparticipation. Public Opinion Quarterly, Vol. 59, pp. 236-258.

Stoop, I., The hunt for the Last respondent, Nonresponse in sample surveys, SCP, Den Haag, Mei 2005

Sykes, Lindsay L., Robin L. Walker, Emannuel Ngwakongnwi and Hude Quan, A Systematic Literature Review on Response Rates across Racial and Ethnic Populations, Canadian Journal of Public Health, May/June 2012, pp. 213-219

Te Riele, Saskia (2002) Vertekening door non-respons. Hoe nauwkeurig zijn de uitkomsten van persoonsenquêtes? Sociaal-economische Maandstatistiek, Jrg. 19 April 2002 


\section{Bijlage 1}

Basiskenmerken populatie, steekproef en responsbestand

\begin{tabular}{|c|c|c|c|c|}
\hline & & Populatie $^{28}$ & Steekproef & Responsbestand \\
\hline Aantal & & $n$ & $n$ & $n$ \\
\hline vmbo & & 86.858 & 8.640 & 2.311 \\
\hline avo & & 76.384 & 2.896 & 971 \\
\hline mbo bol & & 95.515 & 92.223 & 20.653 \\
\hline mbo bbl & & 61.764 & 58.985 & 10.671 \\
\hline hbo & & 63.856 & 57.604 & 21.830 \\
\hline ongedipl. & & 39.831 & 10.804 & 1.839 \\
\hline$\%$ vrouw & & $\%$ & $\%$ & $\%$ \\
\hline vmbo & & 47,9 & 51,7 & 62 \\
\hline avo & & 52,5 & 54,2 & 66,4 \\
\hline mbo bol & & 55,5 & 55,4 & 63,5 \\
\hline mbo bbl & & 38,1 & 38,5 & 45,5 \\
\hline hbo & & 59,1 & 59,3 & 59,7 \\
\hline ongedipl. & & 39,1 & 39,3 & 49,6 \\
\hline$\%$ West-Nederland ${ }^{29}$ & & $\%$ & $\%$ & $\%$ \\
\hline vmbo & & 43,5 & 39 & 38,7 \\
\hline avo & & 46 & 47,9 & 44,4 \\
\hline mbo bol & & 43,1 & 44,5 & 40 \\
\hline mbo bbl & & 42,6 & 39,7 & 41,5 \\
\hline hbo & & 43,2 & 46 & 44,4 \\
\hline ongedipl. & & 49,9 & 52,7 & 50,1 \\
\hline $\begin{array}{l}\% \quad \text { niet-westerse } \\
\text { allochtonen }\end{array}$ & & $\%$ & $\%$ & $\%$ \\
\hline vmbo & & 16,8 & 12,7 & 8,4 \\
\hline avo & & 9 & 9,6 & 8,1 \\
\hline mbo bol & & 23,5 & 23,4 & 16,6 \\
\hline $\mathrm{mbo} b b l$ & & 10,5 & 10,4 & 8,9 \\
\hline $\mathrm{hbo}^{30}$ & & 10 & -- & 6,9 \\
\hline ongedipl. & & 27,5 & 26,7 & 18,7 \\
\hline Niveau & & $\%$ & $\%$ & $\%$ \\
\hline \multirow[t]{4}{*}{ vmbo } & basisber. Iw & 21,2 & 27,7 & 22,1 \\
\hline & kaderber. Iw & 27,9 & 29,6 & 28,6 \\
\hline & gemengde Iw & 9,6 & 14 & 17,7 \\
\hline & theoretische Iw & 41,1 & 28,7 & 31,6 \\
\hline \multirow[t]{2}{*}{ avo } & havo & 57,9 & 55,1 & 49,6 \\
\hline & vwo & 42,1 & 44,9 & 50,4 \\
\hline \multirow[t]{4}{*}{$\mathrm{mbo}$ bol } & niveau 1 & 4,7 & 4,7 & 3,8 \\
\hline & niveau 2 & 21,2 & 21,1 & 18,1 \\
\hline & niveau 3 & 21,9 & 21,7 & 20,7 \\
\hline & niveau 4 & 52,2 & 52,5 & 57,4 \\
\hline \multirow[t]{2}{*}{ mbo bbl } & niveau 1 & 9 & 8 & 7 \\
\hline & niveau 2 & 37,8 & 38,2 & 34,8 \\
\hline
\end{tabular}

\footnotetext{
${ }^{28}$ Bron: DUO en Vereniging Hogescholen

${ }^{29}$ West-Nederland: Provincies Noord-Holland, Zuid-Holland, Utrecht en Zeeland. Voor het hbo is dit gebaseerd op de provincie waar de hogeschool gevestigd is, voor de overige onderwijsniveaus is dit gebaseerd op de woonplaats tijdens het studiejaar 2011/2012.

${ }^{30}$ De steekproef is gebaseerd op de aangeleverde alumnigegevens van hogescholen. Deze zijn exclusief achtergrondkenmerken zoals geboorteland en etniciteit. Voor het responsbestand kan de etniciteit voor het hbo bepaald worden op basis van vragen uit de vragenlijst.
} 


\begin{tabular}{|c|c|c|c|c|}
\hline & niveau 3 & 33,6 & 33,9 & 34 \\
\hline & niveau 4 & 19,6 & 19,9 & 24,2 \\
\hline \multirow[t]{3}{*}{ hbo } & associate degree & 2 & 1,7 & 1,5 \\
\hline & bachelor & 92,5 & 93,4 & 93,4 \\
\hline & master & 5,4 & 4,8 & 5,1 \\
\hline \multirow[t]{4}{*}{ ongedipl. } & vmbo & 19,1 & 29,5 & 32,3 \\
\hline & avo & 6,5 & 7,1 & 12,1 \\
\hline & mbo bol & 56,3 & 45,5 & 40,6 \\
\hline & $\mathrm{mbo}$ bbl & 18,3 & 17,9 & 15 \\
\hline Sector & & $\%$ & $\%$ & $\%$ \\
\hline \multirow[t]{5}{*}{ vmbo } & landbouw & 9 & 41,3 & 41,2 \\
\hline & techniek & 14,8 & 7,8 & 6,1 \\
\hline & economie & 14,8 & 8,4 & 6,4 \\
\hline & gezondheidszorg & 16,8 & 9,5 & 11,1 \\
\hline & algemeen & 44,6 & 33 & 35,2 \\
\hline \multirow[t]{5}{*}{ mbo bol } & landbouw & 5,3 & 4,3 & 4,5 \\
\hline & techniek & 18,7 & 19,1 & 18,3 \\
\hline & economie & 39,9 & 40 & 35,7 \\
\hline & gezondheidszorg & 22 & 22,4 & 24,6 \\
\hline & gedrag en maatsch. & 14 & 14,3 & 16,8 \\
\hline \multirow[t]{5}{*}{ mbo bbl } & landbouw & 8,2 & 5,8 & 4,7 \\
\hline & techniek & 42,9 & 44,3 & 37,8 \\
\hline & economie & 23,9 & 24,3 & 24,7 \\
\hline & gezondheidszorg & 19,1 & 19,6 & 25,1 \\
\hline & gedrag en maatsch. & 5,9 & 6,1 & 7,7 \\
\hline \multirow[t]{7}{*}{$\mathrm{hbo}^{31}$} & landbouw & 2,2 & 2,5 & 2,7 \\
\hline & onderwijs & 15,5 & 12,4 & 12,8 \\
\hline & techniek & 16,2 & 15,1 & 16 \\
\hline & economie & 34,4 & 39,2 & 35,6 \\
\hline & gezondheidszorg & 10,5 & 10,5 & 12,1 \\
\hline & gedrag en maatsch. & 16,6 & 12,9 & 13,5 \\
\hline & taal en cultuur & 4,6 & 7,4 & 7,4 \\
\hline
\end{tabular}

\footnotetext{
${ }^{31}$ Gebaseerd op alleen bachelor afgestudeerden.
} 
Bijlage 2

Respons naar achtergrond- en opleidingskenmerken ${ }^{32}$

\begin{tabular}{|c|c|c|c|c|c|c|c|}
\hline & vmbo & avo & $\begin{array}{ll}\text { mbo } & \text { I } \\
\text { regulier } & \\
\end{array}$ & $\begin{array}{l}\text { mbo II } \\
\text { uitbreiding }\end{array}$ & hbo & ongedipl. & totaal \\
\hline & $\%$ & $\%$ & $\%$ & $\%$ & $\%$ & $\%$ & $\%$ \\
\hline Totale respons & 26,8 & 33,6 & 19,8 & 21,1 & 39,7 & 17 & 25,7 \\
\hline \multicolumn{8}{|l|}{ Geslacht } \\
\hline man & 21,1 & 24,7 & 15,3 & 17,8 & & 14,2 & 17,3 \\
\hline vrouw & 32,1 & 41,1 & 23,9 & 24,5 & & 21,5 & 24,9 \\
\hline \multicolumn{8}{|l|}{ Regio } \\
\hline West Nederland & 26,6 & 31,3 & 18,3 & 20,1 & 38,3 & 16,2 & 24,9 \\
\hline Nederland overig & 26,9 & 35,8 & 20,1 & 22 & 40,8 & 18 & 26,4 \\
\hline \multicolumn{8}{|l|}{ Etniciteit } \\
\hline Westerse allochtonen & 23,3 & 24,4 & 17,4 & 18,7 & & 14,2 & 18,4 \\
\hline $\begin{array}{ll}\text { niet- } & \text { westerse } \\
\text { allochtonen } & \end{array}$ & 17,6 & 28,7 & 13,3 & 16,5 & & 11,9 & 15,7 \\
\hline autochtonen & 28,4 & 34,9 & 20,8 & 22,4 & & 19,4 & 22,5 \\
\hline \multicolumn{8}{|l|}{ Niveau vmbo } \\
\hline basisber. Iw & 21,4 & & & & & & 21,4 \\
\hline kaderber. Iw & 25,8 & & & & & & 25,8 \\
\hline gemengde Iw & 33,7 & & & & & & 33,7 \\
\hline theoretische Iw & 29,5 & & & & & & 29,5 \\
\hline \multicolumn{8}{|l|}{ Niveau avo } \\
\hline havo & 30,3 & & & & & & 30,3 \\
\hline vwo & 37,7 & & & & & & 37,7 \\
\hline & & & & & & & \\
\hline \multicolumn{8}{|l|}{ Niveau bol } \\
\hline niveau 1 & & & 13,7 & 19,2 & & & 18,1 \\
\hline niveau 2 & & & 17,2 & 19,8 & & & 19,2 \\
\hline niveau 3 & & & 21,2 & 21,5 & & & 21,4 \\
\hline niveau 4 & & & 23,6 & 24,6 & & & 24,3 \\
\hline totaal & & & 21,3 & 22,6 & & & 22,3 \\
\hline \multicolumn{8}{|l|}{ Niveau $b b l$} \\
\hline niveau 1 & & & 13,6 & 17,4 & & & 16 \\
\hline niveau 2 & & & 13 & 17,4 & & & 16,6 \\
\hline niveau 3 & & & 16,8 & 18,4 & & & 18,2 \\
\hline niveau 4 & & & 21,8 & 22,2 & & & 22,1 \\
\hline totaal & & & 15,8 & 18,7 & & & 18,2 \\
\hline \multicolumn{8}{|l|}{ Niveau hbo } \\
\hline associate degree & & & & & 365 & & 36.5 \\
\hline bachelor & & & & & 39,5 & & 39,5 \\
\hline master & & & & & 43,8 & & 43,8 \\
\hline \multicolumn{8}{|l|}{ Niveau ongedipl. } \\
\hline vmbo & & & & & & 18,7 & 18,7 \\
\hline
\end{tabular}

32 Voor de VO- en BVE-monitoren zijn scholen die niet via de adressenbestanden van DUO hebben deelgenomen niet in de cijfers van deze tabel opgenomen vanwege een gebrek aan informatie met betrekking tot kenmerken van de non-respondenten van deze scholen. Voor de hbo-afgestudeerden zijn eveneens niet voor alle kenmerken de gegevens van de non-respondenten beschikbaar. 


\begin{tabular}{|c|c|c|c|c|c|c|c|}
\hline avo & & & & & & 29,1 & 29,1 \\
\hline mbo bol & & & & & & 15,2 & 15,2 \\
\hline mbo bbl & & & & & & 14,2 & 14,2 \\
\hline \multicolumn{8}{|l|}{ Sector } \\
\hline algemeen & 28,6 & 33,6 & & & & 22,6 & 28,4 \\
\hline landbouw & 26,7 & & 19,5 & 17,4 & 41,5 & 17,5 & 24,1 \\
\hline onderwijs & & & & & 41,4 & & 41,4 \\
\hline techniek & 20,8 & & 15,9 & 18,4 & 42,1 & 14,1 & 21,5 \\
\hline economie & 20,4 & & 17,7 & 19,8 & 35,7 & 13,4 & 23,8 \\
\hline gezondheidszorg & 31,3 & & 23,2 & 24,4 & 45,3 & 18,9 & 27,4 \\
\hline gedrag en maatsch. & & & 25,3 & 25,7 & 41,3 & 18,9 & 30 \\
\hline taal en cultuur & & & & & 40,4 & & 40,4 \\
\hline
\end{tabular}

